\title{
Inhaltsverzeichnis,
}

Einleitung.

Einführung in das Problem des Dandysmus . . . . . . . . I

\section{Kapitel I.}

Historische Ableitung der Definition des französischen Dandy und

Plan der Arbeit . . . . . . . . . . . . . . . 6

Kapitel II.

Weltschmerz und Nihilismus vor und nach 1800 .

A. Vorbereitende im 18. Jahrhundert bis zu B. Constant's ${ }_{n}$ Adolphe $^{\alpha} 1816$. . . . . . . . . . . . . . 23

B. Die Kulmination im Byronismus der Romantiker . . . . 30

\section{Kapitel III.}

Hemmungen des Nihilismus. Erste Dandies um 1830.
A. Balzac $1799-1850$. . . . . . . . . . . . 38
B. Stendbal $1783-1842$. . . . . . . . . . . . . . 4I
C. Mérimée $1803-1870$. . . . . . . . . . . . . . 45

Kapitel IV.

Vergeistigung des Dandysmus gegen 1860.

A. Der ästhetische Dandysmus Flaubert's $1821-1880$. . . 49

B. Der perverse Dandysmus Baudelaire's $1821-67$. . . . 52

Kapitel $\nabla$.

Letzte Dandies und Abkehr vom Dandysmus.

A. Huysmans wird Mystiker . . . . . . . . . . 58

B. Bourget wird gläubiger Reaktionär . . . . . . . . 63

C. Barrts wird Nationalist . . . . . . . . . . 70

Beschlufs . . . . . . . . . . . . . . . . 78 
